\title{
Kurumsal Kaynak Planlamasının İşletme Performansı Üzerine Etkisi: Bir Alan Araştırması
}

\author{
Selma KARABAŞ \\ Duygu UYSAL ${ }^{2}$ \\ Osman KARKACIER ${ }^{3}$
}

\begin{abstract}
Özet
Kurumsal Kaynak Planlaması (ERP) işletmelerin tedarikçilerinden müşterileriyle olan ilişkilerine kadar, tüm iş süreçlerini bütünleştiren bir paket programdır. Bu çalışmada, ERP kullanımı ile işletme performansı arasındaki ilişki araştırılmıştır. Öte yandan; ERP kullanmayı düşünen KOBI'lerin sistemden beklentileri ve ERP kullanan işletmelerin ise sektörel bazda memnuniyet düzeyleri de incelenmiştir. Yüksek maliyet ve zorlu bir uyum süreci gerektiren bir program olan ERP'nin işletme performansı üzerine olumlu etkisinin olup olmadığının istatistiki açıdan test edilmesi önemli görülmüştür. $\mathrm{Bu}$ amaç doğrultusunda araştırmanın hipotezleri; ERP sistemini kullanan işletmelerin kullanım öncesi ve sonrasında; karlılık, verimlilik, rekabet ve esneklik (talep değişmelerine karşı hızlı cevap verme) değerleri dikkate alınarak Wilcoxon İlişkili İki Örneklem testi ile sınanmıştır. Elde edilen bulgulara göre; ERP'nin işletme performans değerlerini olumlu yönde etkilediği sonucuna ulaşılmıştır.
\end{abstract}

Anahtar Kelimeler: Kurumsal Kaynak Planlaması (ERP), İşletme Performansı

\section{Enterprise Resource Planning Business Value of Performance Effects: Area Survey}

\begin{abstract}
ERP (Enterprise Resource Planning) is a software programme that integrates all business processes to customers relationship from the enterprise supplier. In this study is search to relationship between the using of Enterprise Resource Planning and business performance. In adition to, having been analyzed expectation which is plan using firms to ERP and also examined the satisfaction level of using firms to ERP on a sectoral basis. It is important to test statistically to determine whether there is a positive effect on firm performance because of ERP program that requires high cost and a challenging integration process. For this purpose, the hypothesis of the research have been tested with Wilcoxon Related Two-Sample Test to test whether there is a significant difference between the level of profitability, productivity, flexibility and competition that was take account of values before using and after using of the firms with installation of ERP system. According to the results of research, Enterprise Resource Planning has affected as positive business performance values.
\end{abstract}

Key Words: Enterprise Resource Planning (ERP), Business Performance

\section{Giriş}

Teknolojinin bilgi sistemleriyle bütünleşmesi, işletmelerin iş yapış tarzlarını etkilediği gibi, yönetim sistemlerini de etkilemiştir. Üretim odaklı anlayıştan, müşteri odaklı anlayışa doğru yönelen işletmelerin rekabet araçları da maliyet ve kalite kavramlarından hız ve esneklik kavramlarına doğru kaymıştır. Ürün özelliklerinin birbirine yaklaşması, işletmelerin yeni yazılım ve teknolojileri

\footnotetext{
${ }^{1}$ Yrd. Doç. Dr., Çankırı Karatekin Üniversitesi, İşletme Bölümü, selmakarabas@karatekin.edu.tr

${ }^{2}$ Yüksek Lisans Öğrencisi, Çankırı Karatekin Üniversitesi, Sosyal Bilimler Enstitüsü, duuysal@gmail.com

${ }^{3}$ Prof. Dr., Akdeniz Üniversitesi, İktisat Bölümü, okarkacier@gmail.com
} 
Yalova Sosyal Bilimler Dergisi

kullanarak bütünleştirilmiş yönetim sistemleri aracılığıyla rekabet avantaj1 sağlamasını gerekli kılmaktadır. Tüm kaynakların; tedarik zinciri, stok, müşteri ve üretim ilişkileri, finansal muhasebe, maliyet ve yönetim muhasebesi, insan kaynakları yönetimi, vb. birimler arasında entegrasyonunu sağlayan yönetim ve bilişim sistemleri yalnızca büyük ölçekli üretim/hizmet ya da kamu/vakıf işletmeleri için değil, bunun yanı sıra KOBI'ler için de üstünlük sağladığı ifade edilebilir (Yıldız ve Akaydın, 2012). Öte yandan, bu sistemler işletmelerin bütçe ve kaynaklarını verimli şekilde kullanmalarında ve müşteri memnuniyeti sağlamalarında da etkili bir araç olarak kullanılabilir.

Kurumsal Kaynak Planlaması ile değer zinciri boyunca bilgi akışı tüm birimler arasında eş zamanlı olarak paylaşılmaktadır. Böylelikle, kaynakların dağılımı kontrol altında tutularak güçlü bir kapasite oluşturulması, doğru kararlar alınması ve performansın artırılmasında etkili bir araç olarak kullanılması mümkün olabilmektedir (Ustasüleyman ve Perçin, 2010). ERP'nin bütünleşik yapısı, geleneksel bilgisayar programlarından ayrılan en önemli özelliği olarak ifade edilmektedir (Dağlar, 2012). Bu yapı sayesinde, rekabetçi baskılara ve piyasa firsatlarına daha hızlı tepki verme, direkt işlem maliyetlerini azaltma, daha esnek ürün konfigürasyonu ve işletme kaynaklarının verimli ve etkin kullanımı gibi çok sayıda fayda sağlandığı bilinmektedir (Demirel ve Karaağaç, 2014).

Bilgisayar destekli programların pahalı olması, bazı işletmelerin ürün çeşidinin az olması, alt üretim tesisinin bulunmaması gibi etkenler, işletmelerin, Kurumsal Kaynak Planlaması kullanmalarında çekimser kalma ya da reddetme nedenleri olarak sıralanabilir (Kağnıcıoğlu vd., 2012). Kurumsal Kaynak Planlaması (KKP, ERP: Enterprise Resource Planning), geleneksel işletme sistemlerinin ve çalışma süreçlerinin rekabet avantajı kazanmak için değiştirilmesi ve etkinleştirilmesi arzusunun bir tezahürü olarak değerlendirilmektedir (Açıkalın, 2008). Atasever (2011)'e göre esnek yazılımlar, bilgi iletişim sistemlerindeki gelişmeler ve çalışanların bilgisayar kullanımındaki bilgi ve deneyiminin artmasına bağlı olarak ortaya çıkmıştır.

İşletmelerin ileri üretim / yönetim sistemlerini kullanmalarında; rekabette öne çıkma isteği ve performansı artırma gibi beklentiler yatmaktadır. İşletme performansını olumlu yönde etkilediği belirtilen ERP sisteminin, performans değerleri üzerine etkisinin istatistiki açıdan anlamlı olup olmadığının belirlenmesi amacıyla yürütülen çalışmanın, özellikle ERP sistemine geçme konusunda tereddüt yaşayan işletmeler için önemli bulgular sunduğu düşünülmektedir. ERP sisteminin işletme performansı üzerinde etkili olup olmadığını araştırırken performans değerleri olarak; rekabet, verimlilik, esneklik ve karlılık boyutları değerlendirmeye alınmıştır. $\mathrm{Bu}$ doğrultuda geliştirilen hipotezler test edilerek, araştırma bulguları yorumlanmıştır.

\section{Kurumsal Kaynak Planlamasının Kuramsal Çerçevesi}

Kurumsal Kaynak Planlamasının tarihçesi 1960'lı yıllara dayanmaktadır. 1960'lı yıllarda IBM şirketinin ilk bilgisayarı piyasaya sürmesiyle ortaya çıkan MRP (Material Requirements Planing-Malzeme İhtiyaç Planlaması) programı, ERP 
Yalova Sosyal Bilimler Dergisi

sistemlerinin başlangıcı olarak görülmektedir. Aslında ihtiyaç planlaması gereksinimi; büyüyen ekonominin getirdiği yoğun talep baskısıyla, üreticilerin yüksek hacimli seri üretime yönelmesi ve böylelikle hedeflenen üretim miktarına yetecek hammadde ve malzemenin tedarik edilmesi konusunun göz ardı edilmesiyle kendini hissettirmiştir. Bu sorunla baş edebilmek için, Malzeme İhtiyaç Planlamas1 (MRP) olarak adlandırılan, hangi zamanda - ne miktarda malzeme tedarik - üretim ya da sipariş verilmesi gerektiğini mevcut stoklara da bakılarak ortaya koyan ve ERP sisteminin de çekirdeğini oluşturan sistem geliştirilmiştir (Bulut, 2013).

Ekonomi ve tüketim eğilimlerinde yaşanan dönüşüm, müşterinin odaklı olmayı gerektirmiştir. Bu anlayış, siparişe yönelik üretime geçişi zorunlu kılmış ve MRP, yetersiz kalmıştır. MRP'den sonra MRP II (Manufacturing Resources PlanningÜretim Kaynakları Planlaması) ile, işletmelerin üretimle ilgili tüm faaliyetleri (satınalma, üretim planlama ve kontrol, ürün maliyetleme, muhasebe, stok yönetimi) tek çatı altında toplanmıştır (Yıldız ve Akaydın, 2012). MRP II yaklaşımı, departmanlar arası iş birliği esasına dayanan takım çalışmasını gerektirmiştir. Umble ve ark. (2003)'e göre MRP II'nin temel amaçlarından biri, işletmelerin ortak bir veritabanı kurarak, sistemin modüllerinin ihtiyaç duydukları girdiyi en doğru ve güvenilir kaynaktan almasının sağlanmasıdır (Bulut, 2013). Etkin bir üretim planlama aracı olarak görülen MRP II; satış, dağıtım ve insan kaynakları işlevlerini de sisteme dâhil etmiştir (Keçek ve Yıldırım, 2009). Öte yandan; ürün geliştirme ile üretim sürecini bütünleştiren, bilgisayar destekli tasarım ve bilgisayar destekli üretimin birleşmesiyle Bilgisayarla Bütünleşik Üretim (Computer Integrated Manufacturing, CIM) sistemleri ve firmaların ürün dağıtım kanallarını yöneten Dağıtım Kaynakları Planlaması (Distribution Resource Planning, DRP) sistemleri de ortaya çıkmıştır.

MRP II sistemlerinin sunduğu fonksiyonların, bir şirketin değişik coğrafi bölgelerdeki faaliyetlerini kontrol altına alma ve koordinasyonu için yeniden tasarlanması gerekliliği, ERP sistemlerinin doğuşuna zemin hazırlamıştır. Böylelikle, çok sayıda alt üretim tesisi olan ya da farklı coğrafyalarda ortak kaynak kullanan işletmeler için bütünleşik bir yazılım geliştirilmiştir. Bu yazılım, Ar-Ge, tedarikçi ilişkileri ve müşteri ilişkileri yönetimini de sisteme entegre ederek işletmelerin karar alma süreçlerini hızlandırmıştır. Krajewski ve Ritzman (1998)'e göre; ERP'nin MRP II'den ayrılan en önemli özelliği, dışsal tedarik zincirine sağlanan erişim olarak belirtilmiştir (Çakır ve Bedük, 2013).

\subsection{Kurumsal Kaynak Planlamasının Avantaj-Dezavantajları ve Sistemden Beklentiler}

ERP; büyük ölçekli ya da KOBİ niteliğindeki tüm üretim ve/veya hizmet işletmelerinin, kaynaklarını etkin ve verimli kullanmasını sağlayan; kurulumu uzun, maliyetli ve üst düzey çaba gerektiren bir süreçtir (Eraslan, 2005). Yazılım işletmelerinin piyasadaki pazar payı sürekli olarak değişmektedir (Sevinç, 2008). ERP paketlerinin, planlama ve üretim alanlarında güçlü, dağıtım ve tedarik alanlarında zayıf kaldığı ifade edilmektedir. (Sevinç ve Akyol, 2008). ERP'den 
Yalova Sosyal Bilimler Dergisi

beklenen faydanın ancak, iyi bir yönetim stratejisi ile desteklendiğinde sağlanabileceği belirtilmektedir (Postacı vd., 2012).

ERP sistemlerinin işletmelere sağladığı avantajlar ve bunun yanı sıra sistemin işletmelere getirdiği yükleri içeren dezavantajlara aşağıda değinilmiştir: (Öztürk, 2003; Sevinç 2008; Özer ve Akça, 2007; Çağlıyan, 2012; Yegül ve Toklu, 2010; Eraslan, 2005; Ömürberk, 2008; Şahin 2007; Postac1 vd., 2012; İlter, 2007):

Avantajlar1;

- Tek bir noktadan gerekli bilgilere ulaşma imkânı tanır,

- Daha geniş kitlelere müşteri tatmini sağlar,

- Gerçek finansal durum ve faaliyet sonuçlarına kolaylıkla ulaşma imkânı olacağından, işletmenin karlılığını dolayısıyla hisse senetlerinin değerini artırır,

- Gerek firma içi gerekse firma dışı sistemleri kullanarak yüksek düzeyde entegrasyonu başarı ile sağlar,

- Piyasadaki tehditlere ve firsatlara daha hızlı tepki vermeyi sağlar,

- ERP, “örgütsel standartlaşma sağlar (O’Leary, 2000),

- Çeşitli yollarla örgütlerin temel yapılarını değiştirerek değer yaratır,

- Stokların optimizasyonunu sağlar,

- Bölgeler ve/veya işyerleri arasında malzeme, işçilik, makine-teçhizat, bilgi gibi üretim ve dağıtım kaynaklarının ortaklaşa ve verimli kullanımını sağlar.

Dezavantajları ise;

- ERP sistemlerinin organizasyona adaptasyonu uzun zaman alır, emek gerektirir ve maliyetlidir,

- Uygulanmalarında başarı oranı düşüktür,

- Her firmanın ihtiyacı birbirinden farklılık gösterdiğinden, anahtar teslim bir proje bulunmamaktadır,

- Firmalar tarafindan ERP enformasyon sistemlerinin organizasyona adaptasyonunu etkileyen faktörler tam olarak anlaşılamamaktadır,

- Sorun oluştuğunda gidermede zorluk yaşanmaktadır,

- ERP sistemleri danışmanlık kuruluşlarından alınan diğer hizmetlerde maliyeti arttırıcı etkiye sahiptir,

- Yazılım esnekliğinde yetersizlik ve özelleştirmede (customization) zorluk mevcuttur,

- Konuya hâkim kalifiye personel yetersizdir ve kullanıcı hatalarına sıklıkla rastlanır.

ERP sistemleri sayesinde, işin daha nitelikli ve hızlı yapılması ile, rakiplere karşı maliyet avantajı elde edilerek, dağıtımda ve Pazar payında iyileşme mümkün olabilecektir (Conrad, 2001). Bunun aksine, sistemden kaynaklanan bir takım sorunlar da bulunmaktadır. ERP sistemlerinin sadece işletme içi iş süreçlerini bütünleştirmek için değil, aynı zamanda şirketin tedarikçileri ve müşterileri arasında da, yani ileri ve geri bağlardaki bilgi akışının sağlanıyor olması da, sistemden beklentilerin artmasına neden olmaktadır (Bayraktar ve Efe, 2006). Sistemi kullanıp kullanmama konusunda çekimser kalan işletmeler beklenti-fayda- 
Yalova Sosyal Bilimler Dergisi

maliyet karşılaştırması yaparak karar verme süreçlerini hızlandırabilmektedir. Ancak, sistemin getirileri konusunda yeterince bilgi sahibi olmayan işletmeler, böylesi bir sistemden hızlıca somut bir çıktı görme beklentisi içine girebilmektedir. Tedarikçilerle olduğu gibi, Ar-Ge ve müşteri ilişkilerinin de düzenlenmesine imkan tanıyan ERP yazılımından beklentiler, zaman içerisinde değişebilmektedir (Postacı ve ark., 2012).

İşletmelerin ERP sistemlerinden beklentilerinin araştırıldı̆̆ çalışmalarda (Ural 2004; Postac1 ve diğerleri, 2012);

- Üretim sisteminin kontrol altına alınması,

- Kaynakların verimli kullanımı,

- İşletme birimleri ve fonksiyonlar arsındaki koordinasyondaki artışın olması,

- Müşteri memnuniyeti,

- İş süreçlerinde iyileşme, eskimiş ve her biri bağımsız çalışan sistemleri yenileyip entegre etme,

- İşletme maliyetlerinde azalma,

- Arka planda yürütülen işlerin otomasyonu,

- Müşterilerle ve tedarikçilerle olan iletişimi güçlendirme,

- Bilgi teknolojileri altyapısını tek sistem altında toplayarak yönetimini kolaylaştırma,

- İş sistemlerini basitleştirmek ve standartlaştırma,

- Coğrafi olarak birbirinden uzak birimler arası koordinasyonu sağlama,

- Stratejik kararlarda iyileşme sağlama gibi beklentilerin olduğu tespit edilmiștir.

Başka bir araştırmada ise, ERP kullanan işletmelerin stok ve personel faaliyetlerinde azalma, üretim ve sipariş yönetimlerinde etkinlik, bilgi akış ve iş süreçlerinde iyileşme bekledikleri tespit edilmiştir (Demir ve Bahadır, 2006). Her işletmeye özel ihtiyaç analizi yapılarak, gerekli modüllerin tespit edilmesinin, iş süreçlerinde iyileşme sağlayacağı ve işletme performansını artıracağı ifade edilmektedir (Aydoğan, 2008: Aktaran: Dulkadir, 2012).

\section{Araștırmanın Yöntemi}

ERP sistemini kullanan işletmelerin, bu yazılımı kullanmaya başladıktan sonra işletme performans değerleri üzerinde olumlu bir etkisinin olup olmadığını araştırmak çalışmanın ana amacını oluşturmuştur. Öte yandan; ERP kullanan işletmelerin sektörel bazda memnuniyet düzeyleri de incelenmiş̧ir. Buna ilave olarak, üç yıl içerisinde ERP sistemini kullanmayı düşünen KOBİ'lerin, sistemden neler beklediği de irdelenen konular arasındadır.

Araştırma verileri, Ankara ilinde faaliyet gösteren toplam 148 imalat sanayi işletmesi ile 2015 Mart-Nisan aylarında gerçekleştirilen yüz yüze anketlere dayanmaktadır. Anket yapılan 148 işletmenin 60'1 ERP sistemini kullanan işletmeler olup; 88' 1 ise kısa sure içerisinde ERP sistemine geçmeyi planlayan işletmelerden oluşmuştur. Araştırmada, ERP sistemini kullanmayan işletmeler için, "üç yıl içerisinde ERP sistemine geçme planları olup olmadığı" sorulmuş ve 
Yalova Sosyal Bilimler Dergisi

belirtilen süre içerisinde bu yönde planları olmayan işletmeler, araştırma kapsamı dışında tutulmuştur. Anket formunun oluşturulmasında, araştırmacı tarafından geliştirilen soruların yanı sıra, literatürde yer alan ilgili çalışmalardan da yararlanılmıştır (Güleş ve Çağlıyan, 2002; Semiz ve ark. 2004). Anket sorularının test edilmesi için 17 işletme ile pilot çalışma gerçekleştirilmiş ve yargı cümlelerinde gerekli düzeltmeler yapılmıştır. Araştırma yöntemi olarak, Wilcoxon İlişkili İki Örneklem testi kullanılmıştır. Veri toplama aracının güvenirliği ve içsel tutarlılığının test edilmesinde Cronbach Alpha Katsayısı kullanılmıştır. Cronbach Alpha katsayısının 0,70 'den yüksek olması içsel tutarlılığın yüksek olduğu anlamına gelir (Nakip, 2003). Anket formlarının içsel tutarlıklarının; ERP kullanan işletmeler için 0,882 ve yakın gelecekte ERP kullanmayı düşünen işletmeler için 0,717 olduğu tespit edilmiştir.

Anket formu toplam 60 sorudan oluşmaktadır. Bu sorulardan 30'u firma yapısı ile ilgili genel sorulardan oluşmaktadır. Diğer sorular ise; sadece ERP kullanan işletmelerin cevaplayacağ 1 , sadece ERP kullanmayı düşünen işletmelerin cevaplayacağı ve her iki tip işletmenin de ortak olarak cevaplandıracakları sorulardan oluşmaktadır. Anket formunda 7'li likert ölçeği kullanılmıştır. Formda likert ölçeği ifadelerinin dışında açık uçlu sorulara yer verilmiş, bunun yanı sıra çoktan seçmeli ve birden fazla seçeneğin işaretlenebildiği sorular da anket içerisinde yer almıştır. Verilerin analizinde SPSS 21.0 paket program kullanılmıştır. Elde edilen bulguların değerlendirilmesinde; basit indeks hesaplamaları, oran, frekans analizleri ve çapraz tablolardan yararlanılmıştır. ERP kullanan işletmelerde, sistemin kullanımı öncesi ve sonrasında ERP'nin performans değerleri üzerine etkisinin tespit edilmesinde kullanılan Wilcoxon İlişkili İki Örneklem Testi, özellikle deneme modelli araştırmalarda öncesi ve sonrası değerlerin karşılaştırılmasında kullanılan parametrik olmayan bir test tekniğidir. Belli bir gurubun ilişkili fakat farklı iki uygulama ya da konuya ilişkin görüşlerinin karşılaştırılmasında da kullanılan bir istatistiktir (Eymen, 2007). Wilcoxon testi, parametrik bir test olan t testine alternatif bir testtir. Parametrik olan $\mathrm{t}$ testinde değerlendirmede aritmetik ortalama kullanılırken, parametrik olmayan Wilcoxon testinde karşılaştırmada medyan kullanılmaktadır (Akgül ve Çevik, 2005).

\section{Araştırma Bulguları ve Tartışma}

\subsection{Betimsel Araştırma Sonuçları}

148 adet imalat sanayi işletmesi ile yapılan anketlerden elde edilen bulgulara dayanan araştırmada; 60 işletme ERP kullanan, 88 işletme ise ERP kullanmayan ancak yaklaşık 3 yıl içerisinde ERP'ye geçmeyi planlayan işletmelerdir. Araştırmada ilk olarak, ERP kullanan ve kullanmayan işletmelerin sektörlere göre incelenmiş ve dağılımları Çizelge 1'de verilmiştir. ERP sisteminin; gıda, elektronik, makine ve tekstil sektörlerinde yakın oranlarda kullanıldığı tespit edilmiştir. ERP kullanmayan işletmelerin ağırlıklı olarak inşaat sektöründe faaliyet gösteren işletmeler olduğu belirlenmiştir. 
Yalova Sosyal Bilimler Dergisi

Çizelge 1. ERP Kullanan ve Kullanmayan İşletmelerin Sektörlere Göre Dağılımı

\begin{tabular}{|l|r|l|r|}
\hline \multicolumn{2}{|l|}{ ERP Kullanan İşletmeler } & \multicolumn{4}{l|}{ ERP Kullanmayan İşletmeler } \\
\hline Sektörler & $\mathbf{\%})$ & Sektörler & $\mathbf{( \% )}$ \\
\hline Gida-içecek-tütün & 21,7 & Gida-içecek-tütün & 10,3 \\
Giyim-tekstil-deri & 13,3 & Mobilya & 15,9 \\
Mobilya & 8,3 & Makine-metal eşya & 14,3 \\
Makine-metal eşya & 16,7 & Otomotiv & 12,8 \\
Kimya-petrol-lastik & 9,9 & Ana Metal & 11,4 \\
Elektronik-beyaz eşya-TV & 20,0 & İnşaat & 31,6 \\
Savunma sanayi & 5,0 & Madencilik & 3,7 \\
Madencilik & 5,1 & & 100,0 \\
Toplam & 100,0 & Toplam & \\
\hline
\end{tabular}

ERP kullanan ve kullanmayan işletmelerin stok tutma düzeylerinde fark olup olmadığı araştırılmak istenmiştir. Buna ilişkin bulgular Çizelge 2'de karşılaştırmalı olarak verilmiştir. Modern üretim ve yönetim sistemlerinin tercih edildiği işletmelerde, tedarikçilerle iyi ilişkiler kurmanın, işletmelerin stok düzeylerini düşürdüğü ifade edilmektedir (Kağnıcıoğlu vd., 2012). Tam zamanında üretim, yalın üretim, esnek üretim sistemleri gibi modern sistemlerde işletmelerin stok düzeylerinin mümkün olan en düşük seviyede tutulması amaçlanır. Çizelge 2 incelendiğinde; ERP kullanan işletmelerin \%26,7'sinin, ERP kullanmayan işletmelerin ise \%41'inin yüksek stokla çalıştığı görülür. ERP kullanan işletmelerin, kullanmayanlara göre daha düşük stok bulundurduğu ifade edilebilir.

Çizelge 2. ERP Kullanan ve Kullanmayan İşletmelerin Stok Düzeyleri

\begin{tabular}{|c|c|c|c|}
\hline \multicolumn{2}{|c|}{ ERP Kullanan İșletmeler } & \multicolumn{2}{|c|}{ ERP Kullanmayan İsletmeler } \\
\hline Stok Düzeyi & $(\%)$ & Stok Düzeyi & $(\%)$ \\
\hline Yüksek stok & & Yüksek stok & 40,9 \\
\hline Normal stok & & Normal stok & 32,9 \\
\hline Düşük stok & & Düşük stok & 26,1 \\
\hline Toplam & & Toplam & 100,0 \\
\hline
\end{tabular}

İşletmeler için yatırımın geri dönüş süresi önemlidir. Bir işletme yapmış olduğu yatırımın en kısa sürede kendini amorti ederek kara geçmesini ister. Bu süre her işletme için bulunduğu sektöre, işletme ölçeği ve yatırımın büyüklüğüne göre değişebilmektedir. Araştırmaya dâhil edilen işletmeler KOBİ niteliği taşıdığından, karşılaştırma yapmak ve buna ilişkin kabul edilebilir bir değer bulmak kabul edilebilir olacaktır. Araştırma bulgularına göre; ERP kullanan işletmelere, ERP'nin yatırım maliyetinin geri ödeme süresi sorulmuş ve alınan cevaplara göre ortalama 3 yıl olduğu tespit edilmiştir. Yöneltilen bir diğer soru; "Bu sisteme geçme kararında etkili olan en önemli faktörün ne olduğu"dur. Yapılan değerlendirmelerde; üç temel faktörün öne çıktı̆̆ı belirlenmiştir (Çizelge 3). Bu faktörler sırasıyla; "birimler arası koordinasyonu sağlamak $(\% 33,3)$, iş süreçlerinde iyileşme sağlamak $(26,6)$ ve müşteri ve tedarikçilerin isteklerine hızl cevap vermek (esneklik) (\%20)" şeklinde ifade edilmiştir. Sisteme geçişte karşılaşılan en önemli sorunun, \%46,7 ile, altyapının uygun hale getirilmesi aşamasında yaşandığı tespit edilmiştir (Çizelge 3). Araştırma kapsamında görüşülen işletmelerin sadece \%5'inin, kuruluşundan itibaren ERP yazılımını kullandığ 1 belirlenmiştir. ERP kullanan işletmelerin \%46'sının siparişe göre, \%30’unun seri üretim ve \%23,4'ünün karma üretim yapan işletmelerden oluştuğu tespit edilmiştir. ERP kullanan 
Yalova Sosyal Bilimler Dergisi

işletmelerin \%66,7'si, ERP'yi önemli bir rekabet arac1 olarak görmektedir. ERP kurulumu öncesinde en sorunlu alanın, insan kaynakları yönetimi ve tedarik zinciri yönetimi alanlarında yaşandığı ortaya çıkmıştır. Araştırılmak istenen bir diğer konu; sisteme karş1 personelin direnç gösterip göstermediği konusudur. Kurulum süreci ve sonrasında personelin ERP'yi kabullenmesinin zaman aldığı bulgusuna ulaşılmıştır. ERP yazılımı temel bazı modüllerin dışında çok sayıda modülden oluşan bir yazılımdır. Yapılan araştırma ile, işletmelerin ortalama 6 modül kullandığı görülmüştür. ERP kurulumu öncesinde işletmelerin karşılaştığı genel problem düzeyinin yüksek olduğu belirtilmiş, kurulum sonrasında problem düzeyinin ciddi oranda (\%70) azaldığı işletmeler tarafından ifade edilmiştir. ERP kullanan işletmelerin mevcut teknoloji kullanım düzeyinin yüksek olduğu belirlenmiştir. İşletmelerin tamamının web sitesinin bulunması dikkat çekici bir sonuçtur. İşletmelerin yarısı, son 3 yıl içerisinde üretim teknolojileri kullanımında bir değişme olmadığını belirtirken; diğer yarısı ileri üretim teknolojileri kullanım düzeyinin arttı̆̆ını ifade etmiştir. ERP sisteminin, işletmelerin $\% 25^{\prime}$ 'i tarafından işletmenin kurumsallaşmasında önemli bir araç olarak görülmesi de elde edilen diğer önemli bulgular arasında yer almıştır.

Çizelge 3. ERP Kullanan İşletmelerin Kurulum Kararını Etkileyen Faktörler ve Karşılaşılan Sorunlar

\begin{tabular}{|l|r|l|r|}
\hline \multicolumn{2}{|l|}{$\begin{array}{l}\text { ERP Kurulum Kararını Etkileyen } \\
\text { 1. Önemli Faktör }\end{array}$} & \multicolumn{2}{l|}{$\begin{array}{l}\text { ERP Geçiş Aşamasında Karşılaşılan } \\
\text { En Önemli Sorun }\end{array}$} \\
\hline İfadeler & $\mathbf{( \% )}$ & İfadeler & $\mathbf{( \% )}$ \\
\hline $\begin{array}{l}\text { Maliyetlerde azalma ve verim elde } \\
\text { etme }\end{array}$ & 6,7 & $\begin{array}{l}\text { Kuruluşundan itibaren ERP } \\
\text { kullananlar }\end{array}$ \\
İş süreçlerinde iyileşme & 26,6 & $\begin{array}{l}\text { Personelin sisteme uyum } \\
\text { sağlamasında karşılaşılan sorunlar }\end{array}$ & 15,0 \\
Birimler arası koordinasyonu sağlama & 33,3 & Nitelikli işgücü bulma skııntısı & 13,3 \\
$\begin{array}{l}\text { Müşteri ve tedarikçilerin isteklerine } \\
\text { hızlı cevap verme (Esneklik) }\end{array}$ & 20,0 & Kurulumun maliyetli olması & 20,0 \\
Stok miktarını düşürme & 10,1 & $\begin{array}{l}\text { Sisteme geçiş aşamasında } \\
\text { altyapının uygun hale getirilmesi }\end{array}$ & 46,7 \\
Ürün çeşidinin artması & 3,3 & Total & 100,0 \\
Toplam & 100,0 & & \\
\hline
\end{tabular}

ERP kullanmayan, ancak yakın gelecekte sisteme geçmeyi düşünen işletmelerin ERP'ye geçmeyi düşünmelerinde etkili olan en önemli faktörlere ilikin değerler Çizelge 4'de verilmiştir. Elde edilen bulgulara göre, ERP kullanmayan işletmelerin \%64,4'ü siparişe göre üretim yaparken, \%19,1'i seri üretim yapan işletmelerden oluşmaktadır. İşletmelerin yakın gelecekte ERP kullanmayı düşünmelerinde etkili olan faktörler sırasıyla; "aksaklıkları giderme ve kayıpları önleme (\%37) ve iş yönetiminin kolaylaşması $(\% 32,2)$ " olarak tespit edilmiştir. İşletmelerin ERP'den beklentilerinin bu iki faktör üzerinde yoğunlaştığı belirlenmiştir. Bu bulgulara göre; ERP kullanmayan işletmelerin en fazla iş akışı ve yönetimsel sorunlar ile üretim ve verim kayıpları alanlarında problem yaşadıkları yorumu yapılabilir. Yine, ERP kullanmayan işletmelerin yarıya yakını $(\% 49,5)$ tarafından da ERP'nin işletmeler için önemli bir rekabet aracı olarak görülmesi, sisteme geçmeyi düşünmelerini açıklayan bir sonuç olarak görülmektedir. 
Yalova Sosyal Bilimler Dergisi

Çizelge 4. ERP Kullanmayan İşletmelerin, ERP'ye Geçmeyi Düşünmelerinde Etkili En Önemli Faktör

\begin{tabular}{lc}
\hline İfadeler & $(\mathbf{\% )}$ \\
İş yönetiminin kolaylaşması & 32,2 \\
Hammadde temini ve zaman kaybının önlenmesi & 4,3 \\
Karlılığın yükselmesi & 2,4 \\
Müşteri ihtiyaçlarına cevap hızlı verebilmek & 11,0 \\
Aksaklıkları giderme ve kayıpları önleme & 37,0 \\
Verimliliği artırma & 6,3 \\
Stok düzeyini düşürme & 3,7 \\
Şirketler arası entegrasyonu sağlamak & 3,1 \\
Toplam & 100,0 \\
\hline
\end{tabular}

ERP kullanmayan işletmelerin, ERP sistemine geçmeyi düşünmelerinde etkili olan faktörlerin üretim türlerine göre dağılımı Çizelge 5'de verilmiştir. Buna göre, siparişe göre üretim yapan işletmelerde $\% 50$ ile iş yönetiminin kolaylaşması, seri üretim işletmelerinde $\% 57,8$ ile müşteri ihtiyaçlarına hızlı cevap verebilme ve karma üretim yapan işletmelerde ise $\% 51,9$ ile aksaklıkları giderme ve kayıları önleme faktörleri ERP'ye geçmeyi düşünmede öne çıkan faktörler olarak tespit edilmiştir.

Çizelge 5. Kullanmayan İşletmelerin Üretim Tiplerine Göre ERP'den Beklentileri

\begin{tabular}{|c|c|c|}
\hline Üretim Tipi & İfadeler & $(\%)$ \\
\hline \multirow{3}{*}{$\begin{array}{l}\text { Siparişe Göre Üretim işletmesi } \\
(64,4)\end{array}$} & İş yönetiminin kolaylaşması & 50,0 \\
\hline & Aksaklıkları giderme ve kayıpları önleme & 44,3 \\
\hline & Verimliliği artırma & 5,7 \\
\hline \multirow{4}{*}{$\begin{array}{l}\text { Seri Üretim İşletmesi } \\
(19,1)\end{array}$} & Hammadde temini ve zaman kaybının önlenmesi & 22,3 \\
\hline & Müşteri ihtiyaçlarına hızlı cevap verebilme & 57,8 \\
\hline & Verimliliği artırma & 4,3 \\
\hline & Şirketler arası entegrasyonu sağlama & 15,6 \\
\hline \multirow{4}{*}{$\begin{array}{l}\text { Karma Üretim işletmesi } \\
(16,5)\end{array}$} & Karlılığın yükselmesi & 14,8 \\
\hline & Aksaklıkları giderme ve kayıpları önleme & 51,9 \\
\hline & Verimliliği artırma & 11,1 \\
\hline & Stok düzeyini düşürme & 22,2 \\
\hline
\end{tabular}

ERP kullanmayan işletmelerin, bugüne kadar sisteme geçmelerini engelleyen faktörlerin neler olduğu araştırılmak istenmiştir. Çizelge 6'da elde edilen bulgulara göre; işletmelerin ERP kullanmama sebepleri arasında, "teknik altyapının hazır olmayış1" faktörü $\% 53,4$ 'lük oranla öne çıkmıştır.

Çizelge 6. ERP Kullanmayan İşletmelerin Bugüne Kadar ERP Kullanmamalarında Etkili Faktörler

\begin{tabular}{lr}
\hline İfadeler & $\mathbf{( \% )}$ \\
Yüksek maliyetli oluşu & 20,5 \\
Uzun zaman gerektirmesi & 22,7 \\
İşletmenin teknik altyapısının hazır olmayışı & 53,4 \\
İhtiyaç hissedilmemesi & 3,4 \\
Toplam & 100,0 \\
\hline
\end{tabular}

ERP kullanmayan işletmelerin, ERP'ye geçmeyi düşünmelerinde etkili olabileceği düşünülerek, kullanmakta oldukları yazılımdan memnuniyet düzeyleri araştırılmak 
Yalova Sosyal Bilimler Dergisi

istenmiştir (Çizelge 7). Anket yapılan işletmelerin \%36,8'i kullanmakta oldukları yazılımdan memnun olmadıklarını ifade etmiştir. İşletmelerin 30,3'ü ise memnun olup olmama konusunda çekimser kalmışlardır. ERP kullanmayan işletmelerin mevcut yazılımlarından çok memnun olduğunu belirtenler sadece $\% 2,4$ oranında kalmıştır. ERP kullanmayan işletmelerde web sitesi bulunma oranı \%68'de kalmıştır. ERP kullanan işletmelerde işletmelerin tamamında web sitesi bulunması, bu işletmelerin yeniliklere ve teknoloji kabulüne daha açı oldukları ile açıklanabilir.

Çizelge 7. ERP Kullanmayan İşletmelerin Bugüne Kadar Kullandıkları Yazılımdan Memnuniyet Düzeyleri

\begin{tabular}{lr}
\hline Ölçek & $\mathbf{( \% )}$ \\
Memnun değilim & 36,8 \\
Kararsızım & 30,3 \\
Memnunum & 30,5 \\
Çok memnunum & 2,4 \\
Toplam & 100,0 \\
\hline
\end{tabular}

ERP kullanan ve kullanmayan işletmelerin en güçlü olduğu yönleri sorulmuş ve sonuçları Çizelge 8'de verilmiştir. ERP kullanan işletmelerin \%40'1 "nitelikli personele sahip olmanın" en güçlü yönleri olduğunu vurgularken; \%33,4'ünün "yüksek teknolojiye sahip olmalarının" kendilerini diğer işletmelerden farklı kılan özellikleri olduğunu ifade etmiştir. ERP kullanmayan işletmelerin ise; \%40,8'i "yüksek kalitede ürün üretmenin" ve \%23,9'u ise "Pazar payı büyüklügünün" kendilerini öne çıkaran faktörler olarak belirtmiştir. Elde edilen bulgular değerlendirildiğinde; ERP kullanan işletmelerin insana ve teknolojiye odaklandığ 1 , ERP kullanmayan işletmelerin ise ürün, ürünün özellikleri ve Pazar payına odaklandığı sonucuna varılabilir.

Çizelge 8. ERP Kullanan ve Kullanmayan İşletmelerin En Güçlü Yönleri

\begin{tabular}{|c|c|c|c|}
\hline \multicolumn{2}{|l|}{ ERP Kullanan } & \multicolumn{2}{|c|}{ ERP Kullanmayan } \\
\hline İfadeler & $(\%)$ & İfadeler & $(\%)$ \\
\hline Müșteri sayıs1 & 13,5 & Fiyat & 12,3 \\
\hline Yüksek teknoloji & 33,4 & Pazar payı & 23,9 \\
\hline Pazar payı & 13,1 & Yüksek kalite & 40,8 \\
\hline Personel niteliği & 40,0 & Personel niteliği & 23,0 \\
\hline Toplam & 100,0 & Toplam & 100,0 \\
\hline
\end{tabular}

İşletmelerin içinde bulunduğu rekabet düzeyini nasıl algıladıkları ve mevcut teknoloji düzeylerinin ne olduğu araştırılmış ve sonuçlar Çizelge 9'da karşılaştırmalı olarak verilmiştir. ERP kullanan işletmeler, kullanmayanlara göre rekabet düzeyini daha yüksek algılamaktadır. İki gurup arasında teknoloji kullanım düzeyi açısından önemli farklar gözlenmemiştir. Bu durum, ERP'ye geçmeyi düşünen işletmelerin belli bir teknoloji düzeyine sahip olduğu ve sisteme geçiş için gerekli teknolojik altyapıyı hazırlaması ile açıklanabilir. 
Yalova Sosyal Bilimler Dergisi

Çizelge 9. ERP Kullanan ve Kullanmayan İşletmelerin Sektörlerindeki Rekabet Düzeyleri

\begin{tabular}{|c|c|c|c|}
\hline \multicolumn{4}{|c|}{ Rekabet Düzeyi } \\
\hline \multicolumn{2}{|l|}{ ERP Kullanan } & \multicolumn{2}{|c|}{ ERP Kullanmayan } \\
\hline İfadeler & $(\%)$ & İfadeler & $(\%)$ \\
\hline Düşük & --- & Düşük & 28,5 \\
\hline Orta & 13,3 & Orta & 9,1 \\
\hline Yüksek & 66,7 & Yüksek & 14,3 \\
\hline Çok yüksek & 20,0 & Çok yüksek & 48,1 \\
\hline Toplam & 100,0 & Toplam & 100,0 \\
\hline \multicolumn{4}{|c|}{ Mevcut Teknoloji Kullanım Düzeyi } \\
\hline \multicolumn{2}{|l|}{ ERP Kullanan } & \multicolumn{2}{|c|}{ ERP Kullanmayan } \\
\hline İfadeler & $(\%)$ & İfadeler & $(\%)$ \\
\hline Düşük & --- & Düşük & 0,8 \\
\hline Orta & 28,3 & Orta & 34,1 \\
\hline Yüksek & 58,4 & Yüksek & 46,6 \\
\hline Çok yüksek & 13,3 & Çok yüksek & 18,5 \\
\hline Toplam & 100,0 & Toplam & 100,0 \\
\hline
\end{tabular}

ERP kullanan ve kullanmayan işletmelerde istihdam edilen personel sayısı Çizelge 10 'da verilmiştir. ERP kullanan işletmelerde mikro ölçekli işletme bulunmazken, ERP kullanmayan işletmelerde 250'den fazla çalışanı olan büyük ölçekli işletme bulunmadığı görülmüş̧ür.

Çizelge 10. ERP Kullanan ve Kullanmayan İşletmelerde Çalışan Sayısı

\begin{tabular}{|c|c|c|c|}
\hline ERP Kullanan & & ERP Kullanmayan & \\
\hline Ífadeler & $(\%)$ & İfadeler & $(\%)$ \\
\hline 10-49 kişi & 20,0 & 1-9 kişi & 2,6 \\
\hline 50-249 kişi & 40,0 & 10-49 kişi & 50,5 \\
\hline 250 den fazla & 40,0 & 50-249 kişi & 46,8 \\
\hline Toplam & 100,0 & Toplam & 100,0 \\
\hline
\end{tabular}

ERP kullanan işletmelerin, bu yazılımdan memnuniyet düzeyleri ve memnuniyetin üretim tiplerine göre dağılımı Çizelge 11'de sunulmuştur. Çizelge incelendiğinde; memnun olmayan işletmenin olmadığı görülür. ERP'den çok memnunum diyenlerin oranı $\% 46,7^{\prime}$ dir. İşletmelerin diğer yarısının, henüz ERP'den bekledikleri sonucu alamadığı söylenebilir. Bu da, büyük oranda geçiş aşamasında olup, yatırımın geri ödeme süresini tamamlamamış olan işletmelerin varlı̆ğ ile ilgilidir.

Memnuniyet, algilanan fayda ile beklenen fayda arasındaki fark olarak tanımlanabilir. İşletmeler memnuniyet düzeylerini ifade ederken, fayda-maliyet karşılaştırması yapmaktadır. Üretim tiplerine göre memnuniyetin dağılımı incelendiğinde; seri üretim işletmelerinin tamamının çok memnun olduğu görülür. $\mathrm{Bu}$ sonuç; seri üretim işletmelerinin hacim olarak fazla, çeşit olarak tek veya az ürün üretmesinden kaynaklanmaktadır. Buna karşıt olarak; siparişe göre üretim yapan işletmelerin çok fazla çeşitlilikte üretim yapması, üretim ve yönetim sürecini zorlamaktadir. 
Yalova Sosyal Bilimler Dergisi

Çizelge 11. ERP Kullanan İşletmelerin Sistemden Genel ve Üretim Tiplerine Göre Memnuniyet Düzeyleri

\begin{tabular}{l|r|r|r|r|}
\hline \multirow{2}{*}{ Düzey } & \multirow{2}{*}{$\begin{array}{c}\text { Genel Yüzde } \\
(\boldsymbol{\%})\end{array}$} & \multicolumn{3}{|c|}{ Üretim Tipi } \\
\cline { 3 - 5 } & & Siparişe Göre & \multicolumn{1}{c|}{ Seri } & \multicolumn{1}{c|}{ Karma } \\
\cline { 3 - 5 } & & $\mathbf{( \% )}$ & $\mathbf{( \% )}$ & $\mathbf{( \% )}$ \\
\hline Memnunum & 53,3 & 85,70 & -- & 50,00 \\
Çok memnunum & 46,7 & 14,30 & 100,00 & 50,00 \\
Toplam & 100,0 & 100,00 & 100,00 & 100,00 \\
\hline
\end{tabular}

\subsection{Wilcoxon İlişskili İki Örneklem Test Sonuçları}

ERP kullanan işletmeler için performans ölçütleri olarak ele alınan verimlilik, karlılık, rekabet ve esneklik değişkenlerinin içsel tutarlılığını belirten Cronbach's Alpha katsayısı 0,909 olarak hesaplanmıştır. Bu bağlamda kullanılan değişkenlerin yüksek güvenirliğe sahip olduğu görülür. Araştırmada varılmak istenen sonuçlar hakkında daha isabetli kararlar alabilmek adına, ERP kullanan işletmelerin performans özellikleri üzerinde ERP'nin etkisini görmek için öncesi ve sonrası karşılaştırma yapmaya olanak tanıyan Wilcoxon İlişkili İki Örneklem Testi kullanılmıştır. Kurgulanan teorik ve kuramsal çerçeve hipotez testleri ile sınanarak, test sonuçlarına göre karara varılmıştır. Araştırmada kurgulanan hipotezler aşağıdaki verilmiştir.

\section{Araştırmada Kullanılan Hipotezler}

Araştırmaya ilişkin dört ayrı hipotez geliştirilmiştir. Geliştirilen hipotezlerin sınanması için, aynı örneklem grubu üzerinde karşılaştırma yapılmasına imkân tanıyan Wilcoxon İlişkili İki Örneklem testi kullanılmıştır. Hipotezlerde kurulum öncesi ve sonrasında ele alınan değişkenlerin düzeyleri bakımından anlamlı bir fark olup olmadığı analiz edilmiştir. Bu doğrultuda geliştirilen hipotezler şu şekildedir;

$\mathbf{H}_{1}$ : ERP kullanan işletmelerde, ERP kurulumu öncesi ve sonras1 verimlilik düzeyleri arasında fark vardır

$\mathbf{H}_{2}$ : ERP kullanan işletmelerde, ERP kurulumu öncesi ve sonrası karlılık düzeyleri arasinda fark vardır

$\mathbf{H}_{3}$ : ERP kullanan işletmelerde, ERP kurulumu öncesi ve sonras1 rekabet düzeyleri arasinda fark vardır

$\mathbf{H}_{4}$ : ERP kullanan işletmelerde, ERP kurulumu öncesi ve sonrası esneklik düzeyleri arasında fark vardır

Tanımlayıcı merkezi dağılım ölçülerinden aritmetik ortalama ve standart sapma değerleri Wilcoxon İlişkili İki Örneklem testi ile karşılaştırmalı olarak incelenmiştir. Wilcoxon İlişkili İki Örneklem karşılaştırmalı testi Z değeri anlamlı bulunanlar yorumlanmıştır. Buna göre ERP kullanımı ile ilgili ilk hipoteze $\left(\mathrm{H}_{1}\right)$ ilişkin, kurulum öncesi verimlilik düzeyi ortalaması 2,93 iken; kurulum sonrası 6,00 düzeyine ulaştığ görülmüştür (Çizelge 12). Elde edilen değerler, kurulum öncesi ve sonrasında verimlilik düzeyinde dikkat çekici bir artış olduğunu göstermektedir. Ancak nu artışın istatistiki olarak anlamlı olup olmadığı test edilmelidir. Wilcoxon İlişkili İki Örneklem test sonuçlarına göre $\mathrm{p}$ değeri $=0,000<0,05$ olup, istatistiksel olarak farkın anlamlı olduğu sonucuna ulaşılmıştır. 
Yalova Sosyal Bilimler Dergisi

ERP'nin işletme performans değerlerinden verimlilik üzerine anlamlı bir etkisinin olduğu anlaşılmıştır.

Hipotez 1: ERP kurulum öncesi ve sonrası genel verimlilik düzeyleri arasında fark vardir.

Çizelge 12. ERP Kurulum Öncesi ve Sonrası Genel Verimlilik Düzeyleri Arasında Farkın Anlamlıığı Test Sonuçları

\begin{tabular}{|c|c|c|c|c|c|c|}
\hline & \multicolumn{2}{|c|}{ ERP Kurulum Öncesi } & \multicolumn{2}{|c|}{ ERP Kurulum Sonras1 } & \multicolumn{2}{c|}{ Wilcoxon Test } \\
\hline & Ortalama & Std. Sapma & Ortalama & Std. Sapma & Z & p-değeri \\
\hline Verimlilik Düzeyi & 2,9333333 & 1,006195497 & 6 & 0,9019752 & $-6,812$ & $0,000<0,05$ \\
\hline
\end{tabular}

$\mathrm{H}_{2}$ hipotezi işletmenin karlılık düzeylerinin karşılaştııılmasına yöneliktir. ERP kurulumu öncesi karlılık düzeyi ortalaması 3,67 iken; kurulum sonrasında 5,73'e çıktı̆̆ görülür. Kurulum öncesi ve sonrası karlılık düzeyleri arasındaki farkın anlamlılığı Wilcoxon İlişkili İki Örneklem testi $\mathrm{p}$ değeri $=0,000<0,05$ ile test edildiğinde; ERP'nin işletme performans ölçüsü olan karlılık üzerinde anlamlı bir fark yarattığı gözlenmiştir.

Hipotez 2: ERP kurulum öncesi ve sonrası karlılık düzeyleri arasında fark vardır.

Çizelge 13. ERP Kurulum Öncesi ve Sonrası Karlılık Düzeyleri Arasında Farkın Anlamlılığı Test Sonuçları

\begin{tabular}{|c|c|c|c|c|c|c|}
\hline & \multicolumn{2}{|c|}{ ERP Kurulum Öncesi } & \multicolumn{2}{|c|}{ ERP Kurulum Sonras1 } & \multicolumn{2}{|c|}{ Wilcoxon Test } \\
\hline & Ortalama & Std. Sapma & Ortalama & Std. Sapma & $\mathrm{Z}$ & p-değeri \\
\hline Karlllk Düzeyi & 3,67 & 1,258 & 5,73 & 1,3 & $-6,6$ & $0,000<0,05$ \\
\hline
\end{tabular}

$\mathrm{H}_{3}$ hipotezi ile ERP kurulum öncesi ve sonrası rekabet düzeyleri arasında anlamlı bir fark olup olmadığı test edilmek istenmiştir. ERP kurulum öncesi rekabet düzeyi ortalaması 3,2 iken; kurulum sonrasında 4,47'ye ulaşmıştır (Çizelge 14). Hipoteze ilişkin $p$ değeri $=0,000<0,05$ olduğundan fark anlamlı bulunmuştur.

$\mathbf{H}_{3}$ : ERP kurulum öncesi ve sonrası rekabet düzeyleri arasında fark vardır.

Çizelge 14. ERP Kurulum Öncesi ve Sonrası Rekabet Düzeyleri Arasında Farkın Anlamlılı̆̆ı Test Sonuçları

\begin{tabular}{|c|c|c|c|c|c|l|}
\hline & \multicolumn{2}{|c|}{ ERP Kurulum Öncesi } & \multicolumn{2}{|c|}{ ERP Kurulum Sonras1 } & \multicolumn{2}{c|}{ Wilcoxon Test } \\
\hline & Ortalama & Std. Sapma & Ortalama & Std. Sapma & Z & p-değeri \\
\hline Rekabet Düzeyi & 3,2 & 1,232 & 4,47 & 1,42 & $-4,977$ & $0,000<0,05$ \\
\hline
\end{tabular}


Yalova Sosyal Bilimler Dergisi

$\mathrm{H}_{4}$ hipotezi ile ERP kurulum öncesi ve sonrası esneklik düzeyleri arasında fark olup olmadığ 1 test edilmek istenmiştir. ERP kurulum öncesi esneklik düzeyi ortalaması 3,33 iken; kurulum sonrası 5,8'e çıkmıştır (Çizelge 15). Wilcoxon İlişkili İki Örneklem test sonuçlarına göre $\mathrm{p}$ değeri $=0,000<0,05$ bulunduğundan, $\mathrm{H}_{4}$ hipotezi kabul edilmiştir.

$\mathbf{H}_{4}$ : ERP kurulum öncesi ve sonrası esneklik düzeyleri arasında fark vardır.

Çizelge 15. ERP Kurulum Öncesi ve Sonrası Esneklik Düzeyleri Arasında Farkın Anlamlılı̆ğı Test Sonuçları

\begin{tabular}{|c|c|c|c|c|c|l|}
\hline & \multicolumn{2}{|c|}{ ERP Kurulum Öncesi } & \multicolumn{2}{|c|}{ ERP Kurulum Sonras1 } & \multicolumn{2}{c|}{ Wilcoxon Test } \\
\hline & Ortalama & Std. Sapma & Ortalama & Std. Sapma & Z & p-değeri \\
\hline Esneklik Düzeyi & 3,33 & 1,258 & 5,8 & 0,659 & $-6,613$ & $0,000<0,05$ \\
\hline
\end{tabular}

\section{Sonuç}

Bilgi ve iletişim teknolojilerindeki gelişmeler, beraberinde işletmeler için rekabetçi piyasa koşullarına uyum sağlamayı gerekli kılmaktadır. Bu da işletmeleri, doğru zamanda, doğru bilgi ile etkin kaynak kullanımını sağlamada önemli bir yönetim aracı olan ERP'ye yöneltmektedir. Değiş̧en Pazar koşulları ve müşteri istekleri, işletmeleri MRP'den ERP'ye kadar uzanan tarihsel bir sürecin içine çekmiştir. Tedarikçilerden müşterilere kadar uzanan ağ içerisinde yer alan tüm iç ve dış birimlerin bütünleştirilmesi ve bilginin, iş yapma ve karar alma sürecinde doğru ve hızlı kullanılmasını sağlayan Araştırma ile, işletme performans ölçütleri olarak ele alınan değişkenler üzerine, ERP'nin anlamlı bir etkisinin olup olmadığ 1 araştırılmıştır. Çalışmada, işletme performans değerleri olarak; verimlilik, karlılık, rekabet ve esneklik (talep değişmelerine hızlı cevap verme) düzeyleri ele alınmıştır.

Araştırma bulgularına göre; ERP kullanan işletmelerde, verimlilik, karlılık, esneklik ve rekabet düzeyleri hipotezler kurularak test edilmiş ve kurulum sonrasında bu değerlerde gözlemlenen artışın istatistiki açıdan anlamlı sonucuna ulaşılmıştır. Özellikle ERP sisteminin, incelenen işletmelerde verimlilik düzeyi üzerinde önemli katkı sağladığı tespit edilmiştir. Birçok işletme için önemli bir sorun olan düşük verimliliğin, ERP sistemi ile giderilebileceği araştırma ile tespit edilmiştir. ERP sistemini kullanma konusunda kararsız olan işletmelerin, sistemden fayda sağlayabilmek ve beklentilerini karşılayabilmek için ortalama 3 y1llık bir uyum sürecine ihtiyacı olduğu da göz önünde bulundurulmalıdır. Sonuç olarak; ERP yazılımının işletme performans değerleri üzerinde olumlu yönde katkı sağladığı belirlenmiştir. ERP sisteminin sağladığı faydalar bunlarla sinırlı olmamakla beraber; bahsedilen pozitif katkıların, çarpan etkisi yaratacağ 1 söylenebilir. Bu bağlamda; Pazar payını artırma, büyüme, tedarikçi ilişkileri yönetiminde etkinlik ve müşteri memnuniyeti sağlama gibi dolaylı etkilerinin olduğu da belirtilebilir. 
Yalova Sosyal Bilimler Dergisi

Araştırmada ERP kullanan işletmelerin \%53,3'ünün “memnun”, \%46,7'sinin ise "çok memnun" olduğu düşünüldüğünde; sisteme dair ciddi bir memnuniyet olduğu dikkat çekmektedir. Sistemden memnun olmayan işletme bulunmamaktadır. Memnuniyet; beklentilerin karşılanma düzeyi ile ilgili bir kavramdır. ERP kullanmayan, ancak kısa ya da orta vadede geçmeyi düşünen işletmelerin, sisteme geçme konusundaki beklentilerinin, özellikle "iş akışıyla ilgili aksaklıkları gidermek ve iş yönetiminin kolaylaşmasını sağlamak" konularında yoğunlaştı̆̆ 1 görülmüş̧ür.

ERP kullanmayan işletmelerin, bugüne kadar ERP sistemine geçmemelerinde etkili olan faktörler araştırılmış ve işletmelerin yarısından fazlasının "teknik altyapının hazır olmaması $(\% 53,4)$ " sebebiyle sisteme geçmedikleri tespit edilmiştir. ERP sistemini kullanan işletmelerin bilgi-teknoloji düzeyinin daha yüksek olduğu ve yeniliklere daha açık oldukları ifade edilebilir.

Bilginin teknolojiyle bütünleştirilmesi ile ortaya çıkan ERP sistemi, yalnızca büyük ölçekli işletmelerin kullanacağ 1 bir sistem olarak düşünülmemelidir. Bu sistem işletmeler için bir zorunluluk olarak görülmese de, ileri üretim ve yönetim teknolojilerinden uzak kalarak, işletmelerin küresel piyasalarda varlığını uzun süre devam ettirmeleri mümkün gözükmemektedir. ERP sisteminin işletme ile uyum sürecinde çalışanlar açısından sorun yaşanmaması için, teknik desteğin ve eğitimin önemi göz ardı edilmemelidir. Her işletmenin kendine has ihtiyaçlarının doğru analiz edilerek, gerekli modüllerin kurulumunun sağlanması, sistemden beklentilerin yüksek oranda karşılanmasını sağlayacak önemli bir unsur olarak ifade edilebilir.

\section{Kaynakça}

Açıkalın, İ.U. (2008). İnşaat Sektöründe Kullanılan Kurumsal Kaynak Planlama Sistemlerinin Bütünleşik Bilgi Yönetimindeki Rolünün İncelenmesi, İstanbul Teknik Üniversitesi Fen Bilimleri Enstitüsü, (Doctoral Dissertation), İstanbul.

Ağayev, S. (2007). Kurumsal Kaynak Planlama (ERP) Sisteminin Seçimi, Kurulumu ve ERP Kullanıcı Firmaların Sistemden Beklentilerinin Analizi, Gazi Üniversitesi Sosyal Bilimler Enstitüsü. (Yayımlanmış Yüksek Lisans Tezi), Ankara.

Akgül, A. ve Çevik, O. (2005). İstatistiksel Analiz Teknikleri: SPPSS’te İşletme Yönetimi Uygulamaları, Emek Ofset, Ankara.

Atasever, A. (2011). Orta Ölçekli Bir Firmada Kurumsal Kaynak Planlama (ERP) Uyarlama Çalışması ve Bir Üretim Çizelgeleme Uygulaması (Doctoral Dissertation), Fen Bilimleri Enstitüsü, İstanbul Ticaret Üniversitesi, İstanbul.

Aydoğan, E. (2008). “Kurumsal Kaynak Planlamasi”, Türkiye Sosyal Araştırmalar Dergisi (TSA), Sayl: 12, s. 107-118.

Bayraktar, E., ve Efe, M. (2006). “Kurumsal Kaynak Planlaması ve Yazılım Süreci”, Selçuk Üniversitesi Sosyal Bilimler Dergisi, 123(15): s.695.

Bulut, S. (2013). Beyaz Eşya Yan Sanayi Sektöründe ERP ve Yalın Üretim Olgunluğu Analizi ve Otomotiv Yan Sanayi ile Klyaslama, İstanbul Teknik Üniversitesi, (Doctoral Dissertation), Fen Bilimleri Enstitüsü, İstanbul.

Çağlıyan, V. (2012). "Kurumsal Kaynak Planlama Yazılımı Kullanımının İşletme Performansı Üzerine Etkisi: Örnek Olay Çalışması”. Niğde Üniversitesi İ̈BF Dergisi, (5):159-178. 
Yalova Sosyal Bilimler Dergisi

Çakır, B.Ö. ve Bedük, A. (2013). “Çalışanların Kurumsal Kaynak Planlaması (ERP) Değerlendirmeleri ve Kurumsallaşma Algıları”/Employees' Evaluations of Enterprise Resource Planning (ERP) and Perceptions of Institutionalization. Selcuk Üniversitesi Sosyal Bilimler Enstitüsü Dergisi, (30), 81.

Demir, M. (2005). “ERP Seçiminde Yama Yaklaşımı”, Crmpro Dergisi, Sayı:13.

Demir, V. ve Bahadır, O. (2006). "Kurumsal Kaynak Planlaması (ERP) Sistemlerinin Maliyetlere ve İşletme Performansına Etkileri”, Muhasebe Bilim Dünyası Dergisi, 8(3) s:57-70.

Demirel, M.Y. ve Karaağaç, İ. (2014). Bilgisayar Destekli Üretim Süreçlerine Genel Bir Bakış. Engineer \& The Machinery Magazine, (652).

Dulkadir, B. (2012). “Tekstil İşletmelerinde Kurumsal Kaynak Planlaması (ERP) Kullanımındaki Memnuniyet Düzeyi ve Malatya İlinde Bir Araştırma". Akademik Yaklaşımlar Dergisi, 3(2): 17-36.

Eraslan, B. (2005). İnşaat Firmalarında Satınalma Yönetimi ve Kurumsal Kaynak Planlaması (ERP) Tabanlı Bir Satın Alma Yönetim Modeli Önerisi, İstanbul Teknik Üniversitesi, Fen Bilimleri Enstitüsü, İstanbul.

Eymen, U.E. (2007). SPSS Kullanma Kılavuzu. İstatistik Merkezi Yayın No:1, E-Kitap; www.istatistikmerkezi.com

Güleş, H.K. ve Çağlıyan, V. (2002). "İleri İmalat Teknolojileri Kullanımının İşletme Performansına Etkileri: Küçük ve Orta Ölçekli Sanayi İşletmelerinde Bir Uygulama". SÜ İ̈BF Sosyal ve Ekonomik Araştırmalar Dergisi.

İlter, K. (2007). "Bilgi Sistemleri Perspektifinde Kurumsal Kaynak Planlamas1; Etkiler ve Değerler". İstanbul Ticaret Üniversitesi Sosyal Bilimler Dergisi, (11): 1-20.

Kağnıcıŏglu, H., Aydın, S., Hasgül, S. ve Anagün. A.S. (2012). Üretim Yönetimi, T.C. Anadolu Üniversitesi Yayını No: 2584, ISBN: 978-975-06-1254-1, Eskişehir.

Keçek, G. ve Yıldırım, E. (2009). "Kurumsal Kaynak Planlaması (ERP) ve İşletme Açısından Önemi”, Dumlupinar Üniversitesi Elektronik Sosyal Bilimler Dergisi, 8(29): s240-258.

Nakip, M. (2003). Pazarlamada Araştırma Teknikleri, Seçkin Yayıncılık, Ankara.

Ömürberk, V. (2003). Kurumsal Kaynak Planlamasında Muhasebe Bilgi Sisteminin Rolü: Gida Sektöründe Bir Uygulama. Süleyman Demirel Üniversitesi, Sosyal Bilimler Enstitüsü, (Doktora Tezi), Isparta.

Özer, G. ve Akça, Y. (2007). "Yenilikçi Özelliklerin Kurumsal Kaynak Planlaması ve Algılanan Organizasyonel Performans Üzerine Etkisi”. ZKÜ Sosyal Bilimler Dergisi, (3):53-70.

Öztürk, K. (2003). Kurumsal Kaynak Planlaması. İstanbul Teknik Üniversitesi, Fen Bilimleri Enstitüsü, (Yüksek Lisans Tezi), İstanbul.

Postac1, T., Belgin, Ö. ve Erkan, E.T. (2012). “KOBİ’lerde Kurumsal Kaynak Planlaması (ERP) Uygulamaları,” T.C. Sanayi, Bilim ve Teknoloji Bakanlı̆̆ı Verimlilik Genel Müdürlüğü, 723: 16.

Semiz, S., Okay, Ş. ve Sekmen, Y. (2004). "İşletmelerde İleri İmalat Teknolojilerinin Kullanım Nedenleri ve Otomotiv Sektöründe Bir Alan Araştırması”. Teknoloji Dergisi, Cilt 7, Sayı 4, 549-556.

Sevinç, N. (2008). Tedarik Zinciri Yönetiminde Bilgi Teknolojilerinin Kullanımı ve Önemi. Trakya Üniversitesi, Sosyal Bilimler Enstitüsü, (Yüksek Lisans Tezi), Edirne.

Şahin, U. (2007). Tekstil Sektöründe ERP Sistemi Seçiminde Uzman Sistem Yaklaşımı. İstanbul Teknik Üniversitesi, Fen Bilimleri Enstitüsü, (Yüksek Lisans Tezi), İstanbul.

Ural, Ö. (2004). Orta ve Büyük Ölçekli Hazır Giyim Isşletmelerinde Kurumsal Kaynak Planlaması (ERP) Yazılımlarının Kullanımı Üzerine Bir Araştırma. Gazi Üniversitesi, Eğitim Bilimleri Enstitüsü, (Yayımlanmış Yüksek Lisans Tezi), Ankara. 
Yalova Sosyal Bilimler Dergisi

Ustasüleyman, T. ve Perçin, S. (2010). "Kurumsal Kaynak Planlaması (ERP) Uygulamalarında Kritik Kontrol (Başarı) Faktörlerinin Etkisine Yönelik Yapısal Bir Model Önerisi”, Marmara Üniversitesi III BF Dergisi, 28(1), 293-312.

Yegül, F.M. ve Toklu, B. (2010). “Türkiye'de ERP Uygulamaları”. Gazi Üniversitesi Mühendislik ve Mimarlık Fakültesi, Endüstri Mühendisliği Dergisi, (15): 2-15.

Yıldız, M.S. ve Akaydin, A. (2012). "Kurumsal Kaynak Planlaması Sistemine Geçiş Yapan Endüstriyel Bir İşletmede Yazılımın Kurulum Süreci ve Yaşanılan Değişimler” Muhasebe ve Vergi Uygulamalari Dergisi (Muvu)/Journal Of Accounting \& Taxation Studies (Jats), 5(1). 